\title{
The Effect of Commitment and Culture on Teacher Job Satisfaction: A Regression Analysis
}

\author{
Supriyati $^{1 *)}$, Happy Fitria ${ }^{2}$, Syaiful Eddy ${ }^{2}$ \\ ${ }^{1}$ SD Negeri 1 Babat Supat, Palembang, Indonesia \\ ${ }^{2}$ Universitas PGRI Palembang, Indonesia \\ *Corresponding author. Email: supriyatipjk@gmail.com
}

\begin{abstract}
This study aims to determine the effect of organizational commitment and organizational culture on teacher job satisfaction. This research was conducted in SD Negeri Babat Supat District, Musi Banyuasin Regency, Indonesia. The number of samples of this study was 75 teachers, who were taken using probability sampling techniques, and were calculated using the Slovin formula. Data collection using a questionnaire. Testing data using linear regression analysis techniques. The results of data analysis show that: (1) organizational commitment and organizational culture simultaneously have a significant effect on teacher job satisfaction; (2) organizational commitment partially significant effect on teacher job satisfaction; and (3) organizational culture has a significant effect on teacher job satisfaction. The results of this study indicate thatthe higher the organizational commitment and organizational culture onteacherthen the teacher's job satisfaction will also increase.
\end{abstract}

Keywords: organizational commitment, organizational culture, teacher job satisfaction

\section{INTRODUCTION}

Teachers have a very important role in the field of education. Quality teachers will create adequate educational resources. Currently, the government is trying to make efforts to reform and perfect the regulations of the education system according to needs and changes. This of course is done as a form of improving the quality of the education sector as a whole through increasing the work productivity of education actors such as teachers.

The professional ability of educators as the basic foundation of the teaching and learning process is very important to improve education which emphasizes improving the quality that exists at every level of education. Professionalism is the act of professionals who are willing to do something as a main job as a profession and not as a free time filler or as mere pleasure. Professionals are responsible for their decisions both mentally and attitudes, and uphold professional ethics in a dynamic organization [1].

However, this would not be possible if it was not accompanied by the efforts of teachers to continuously improve their professional abilities to carry out their duties as teachers. The obligation of teachers to improve their professional abilities is not only useful for themselves, but has a good meaning for efforts to develop the quality of education in general. Any effort made in the field of education is to realize the goals of national education, namely to develop abilities and shape the character and civilization of a nation that has dignity and to educate the nation's life. National education has the function of developing capabilities and shaping the character and civilization of the nation with dignity in the framework of educating the nation's life.

In addition to support, a teacher's commitment to the organization is very important to develop the quality of human resources in schools. Organizational commitment is an action that shows how someone knows and is closely tied to their organization [2]. Organizational commitment can improve work ethic and accelerate the realization of the goals the organization wants. Commitment includes efforts to improve the performance of quality teachers so that these efforts will support the achievement of organizational goals.

The low level of commitment shows the lack of job satisfaction of teachers in schools as the organizations they are involved in. If all the hopes and needs of an educator are achieved, he will survive in serving the school. This condition really supports the commitment of teachers to the school organization where they work. With their commitment, teachers will always work wholeheartedly, be actively involved and develop their thinking and creativity in school organizational activities that will create high teacher work performance.

Every organization has a culture that is used as a guide for each member in carrying out activities and making decisions to achieve good goals. This means that the organization will lead to better development if the organizational culture is well developed. However, 
there are also major pressures that accompany change and efforts to develop organizational culture, such as efforts to remove norms and boundaries for the behavior of all members of the organization.

Organizational culture becomes conceptual systematically which guides work action or behavior in work routines and causes its members to act directed to achieve organizational goals. The agreement that is formed in the organizational culture will facilitate the formation of an agreement in a wider organization for the benefit of individuals. In organizations, culture is the main thing that can control, direct and shape the character of a person who is a member. In addition, the school culture was also identified as being able to improve teacher performance in these schools. Organizational culture is the values contained in a person's attitude and behavior in organizations such as belief in all his actions [3].

Thus organizational culture is very important to achieve organizational goals. Initially the organizational culture will be influenced by the habits of the members of the organization. Organizational culture reflects the personality of the organization. Apart from organizational culture, communication also has an important task. Borganizational culture are behavioral, social, and moral norms that underlie every action in the organization and are shaped by the beliefs, attitudes, and priorities of its members [4]. School is an organization, and the culture in the school is an organizational culture. The culture of the school organization greatly influences the quality of education at the school.

Culture and education are two elements that cannot be separated because they are mutually binding [5]. Culture grows and develops according to the educational process, and education is bound in a cultural context. A mutually recognized organizational culture must be adhered to and implemented with full responsibility. Organizational culture has a partially significant influence on teacher job satisfaction [6]. Then organizational commitment and organizational culture also have a significant effect simultaneously on teacher job satisfaction.

Organizational commitment simultaneously has a significant effect on teacher job satisfaction and organizational commitment has a significant effect on teacher job satisfaction [7]. Organizational culture has a positive and significant effect on job satisfaction [8] There is a positive influence between organizational culture on job satisfaction, there is also a positive influence between organizational commitment on job satisfaction, and there is a significant influence of organizational culture and organizational commitment simultaneously on job satisfaction [9].

Organizational culture has a significant effect on employee job satisfaction, organizational commitment has a significant effect on employee job satisfaction [10]. BOrganizational culture and organizational commitment have a positive and significant effect on employee job satisfaction [11]. There is a significant influence of organizational culture on job satisfaction, there is a significant effect of organizational commitment on job satisfaction, and there is a significant influence of organizational culture and organizational commitment simultaneously on job satisfaction [12].

Teacher job satisfaction is a form of response, whether positive or negative, on the recognition obtained from the situations and conditions experienced by the teacher in relation to their work. The teacher will have job satisfaction if the responses obtained are potential and vice versa. This response (a form of job satisfaction) greatly affects teacher performance.

From the results of observations in the field, it can be seen that there are still teachers who undertake other activities besides teaching, teachers also do not have a strong commitment to become an educator, commitment to school is also still lacking, there is still a poor work culture, income levels that are not optimal and still there is a significant difference in income between permanent teachers and honorarium teachers.

Job satisfaction is relative. Everyone feels different levels of job satisfaction because in general job satisfaction is a level of pleasure or a positive emotional attitude as a result of an assessment of the work done by someone [13]. There are several factors that can affect job satisfaction, including organizational commitment and organizational culture.Organizational commitment plays a very important role in achieving organizational goals. With high commitment, all members of the organization can be sure to work and dedicate wholeheartedly to produce effective and efficient performance. Organizational commitment must go hand in hand with a balanced organizational culture if you want to get high job satisfaction and performance.

That is, commitment and organizational culture have a very important role for the performance of teachers to carry out their duties properly in order to achieve maximum educational goals. There is a significant influence between organizational culture and teacher job satisfaction [14]. Culture is the foundation of an organization. The foundation must be strong, so that it can support all elements of the organization. The organization is expected to be able to divert people's attention to the cultural elements that will be improved. Some of the characteristics of organizational culture include tolerance, personal initiative, goals, management support, control, identity, reward, integration, problem solving, and formal communication [15].

Organizational culture has homogeneous characteristics. Organizational effectiveness depends on understanding and combining all elements that support each other. The higher the percentage of members in accepting and implementing core norms and values, the member work commitment will increase. A strong culture greatly influences the 
behavior of members, because the intensity of togetherness will increase behavior control [15].

According to the explanation of the experts above, it can be concluded that organizational culture plays an important role in identifying and directing organizational behavior in accordance with the principles. A strong school culture affects the entry and exit of teachers in school organizations. Culture directs organizational behavior in making decisions; developing methods for receiving feedback on performance; maintain the reward and reinforcement system that applies in the organization. Culture can provide identity and direction for organizational life to take place.

All organizations are expected to be able to develop organizational behavior that shows honesty and ethics which are communicated in writing and can be used as guidelines by all teachers. Culture must be the foundation of noble values which will guide the ethics of organizational management, which includes professionalism; cooperation; harmony; harmony; balance; and welfare.

Culture performs a number of functions within the organization, namely: culture has a role to define boundaries, culture gives a sense of identity to members of the organization, culture facilitates commitment to something that is broader than one's personal self-interest, culture increases the stability of the social system; Meaning making mechanisms and control mechanisms that guide and shape teacher attitudes and behavior [15].

Highly oriented organizational culture can provide identity, a source of driving and behavior patterns, social cohesion, sources, the ability to increase added value, substitute for formalization, a mechanism of adjustment to change orally and in writing [16]. Meanwhile, there are five functions of oganization culture, namely: (1) as a barrier to behavior in organizations; (2) creating a sense of ownership; (3) convincing members to commit to achieving goals; (4) maintaining social stability in the organization; and (5) controlling the behavior of members of the organization to conform with agreed norms and values [16], [17].

Thus it can be argued that the function of organizational culture is as an introduction to identity, mutual commitment, social system stability, and a channel of understanding. The embodiment of values and norms in organizational culture is closely related to organizational management. The willingness of management to improve ethical behavior can reduce the level of fatal fraud, such as fraud in financial reports, embezzlement of assets, and corruption in the organization.

\section{METHODS}

This study uses a quantitative approach with a survey method, namely by asking a series of questions in the form of a questionnaire to get respondents' answers. With the ex post facto research design, this study aims to investigate the events that have occurred and then according to the hindsight to determine the factors that cause an event [18], [19]. The population in this study were 295 teachers of SD Negeri Babat Supat District, Musi Banyuasin Regency, Indonesia.Sampling using probability sampling techniques, namely sampling techniques that provide equal opportunities for each element (member) of the population to be selected as members of the sample. The number of samples is determined by calculation using the Slovin formula:

$n=\frac{N}{1+N e^{2}}$

Information:

$\mathrm{n}=$ Sample size

$\mathrm{N}=$ Population size

e $=$ Allowance for inaccuracy due to tolerable sampling error, $\mathrm{e}=10 \%$ then squared.

Based on the Slovin formula, the number of samples drawn is: 74.6 rounded off to 75 . Based on the calculation results, the sample obtained is 75 respondents. The number of samples that have been obtained is then divided so that the determination of the number of samples in each school has the same proportion

The data was collected using a closed and scaled questionnaire, which is a questionnaire that has provided a statement, so that the respondent only has to fill in the answers by giving a checklist with alternative answers. The scores available in the questionnaire are: Always given a score of 5; Very often given a score of 4; Often given a score of 3 ; Sometimes given a score of 2 ; and Never given a score of 1. All data obtained from respondents were processed and analyzed using the IBM SPSS Statistics 25 program.

The research variables tested in this study consisted of simultaneous and partial hypothesis testing. Simultaneous hypothesis testing, namely the effect of organizational commitment (X1) and organizational culture (X2) on teacher job satisfaction (Y). While the partial hypothesis test, namely: the effect of organizational commitment (X1) on teacher job satisfaction (Y); and the influence of organizational culture (X2) on teacher job satisfaction (Y).

Partial hypothesis testing using the t test [20], [21]. Hypothesis testing criteria, namely if the probability value (Sig.) $>$ A (0.05); then $\mathrm{Ho}$ is accepted, or if the probability value (Sig.) $<\alpha(0.05)$ then Ho is rejected. Or the hypothesis testing criteria, namely if the value of $t>t_{\alpha(0.05)}$ then Ho is accepted, or if the value of $\mathrm{t}<\mathrm{t}_{\alpha}(0.05)$ then Ho was rejected. Simultaneous hypothesis testing using the F test [20], [21]. The criteria for testing the hypothesis in simultaneous regression, namely if $\mathrm{F}_{\mathrm{Sig}}>\alpha(0.05)$ then Ho is accepted, or if $\mathrm{F}_{\mathrm{Sig}}<\alpha(0.05)$ then Ho is rejected. The coefficient of determination aims to test 
the size of the effect independent variable on the dependent variable. The coefficient of determination can be seen in the RSquare column Model Summary output when calculating regression [22]. While testingThe coefficient of determination can be calculated using the formula:

$K D=r^{2} x 100 \%$; with $r^{2}=\frac{b \Sigma x y}{\Sigma y^{2}}$

\section{Information:}

KD : Coefficient of Determination

r2 : correlation coefficient

\section{RESULTS AND DISCUSSION}

\subsection{The Effect of Organizational Commitment on} Teacher Job Satisfaction

The results of data analysis are based on the partial significance test of the effect of organizational commitment on satisfaction teacher work can be observed in Table 1. Result The data analysis shows that the $t$ value is 5.628 and the t table value is 1.9921 . By comparing the value of $t$ count and table it is known that the value of $t_{\text {arithmetic }}(5.628)>t_{\text {table }}$ (1.9921). The significance value of 0.000 is less than 0.05 . According to the calculation results in Table 2, it can be concluded that there is a significant influence between organizational commitment and teacher job satisfaction. The value of $\mathrm{R}_{\text {Square }} 0.303$ means that the effect of organizational commitment on teacher job satisfaction reaches $30.3 \%$.

Table 1 The Significance of the Effect of Organizational Commitment on Teacher Job Satisfaction

\begin{tabular}{|c|l|c|c|c|c|c|}
\hline \multirow{2}{*}{ Model } & \multicolumn{2}{|c|}{$\begin{array}{c}\text { Unstandardized } \\
\text { Coefficients }\end{array}$} & $\begin{array}{c}\text { Standardized } \\
\text { Coefficients }\end{array}$ & \multirow{2}{*}{$\mathrm{t}$} & \multirow{2}{*}{ Sig. } \\
\cline { 2 - 6 } & B & $\begin{array}{c}\text { Std. } \\
\text { Error }\end{array}$ & Beta & & \\
\hline 1 & (Constant) & 55,603 & 6,244 & & 8,905 & 0.000 \\
\cline { 2 - 7 } & $\begin{array}{l}\text { organizational } \\
\text { commitment }\end{array}$ & 0.331 & 0.059 & 0.550 & 5,628 & 0.000 \\
\hline
\end{tabular}

Table 2 Summary Model Organizational Commitment

\begin{tabular}{|l|l|l|l|l|}
\hline Model & $\mathrm{R}$ & R Square & $\begin{array}{c}\text { Adjusted } \\
\text { R Square }\end{array}$ & $\begin{array}{c}\text { Std. Error } \\
\text { of the } \\
\text { Estimate }\end{array}$ \\
\hline 1 & $.550 \mathrm{a}$ & 0.303 & 0.293 & 6,47218 \\
\hline
\end{tabular}

a. Predictors: (Constant), organizational commitment

b. Dependent Variable: Job satisfaction

\subsection{The Influence of Organizational Culture on Teacher Job Satisfaction}

The model of the relationship between school culture and teacher job satisfaction is expressed in the form of the regression equation $\mathrm{Y}=15.858+0.724$ $\mathrm{X} 2$. The regression equation significance test can be presented in Table 3. The results of the significance test in Table 3 indicate that the hypothesis proposed is that there is an influence of organizational culture on teacher job satisfaction. Evidenced by the acquisition of the $\mathrm{t}$ value of 10.274 is greater than the $\mathrm{t}$ table 1.9921 , and the significance value of 0.000 is less than 0.05 .

The magnitude of the contribution of organizational culture to teacher job satisfaction is obtained from the $\mathrm{R}_{\text {Square }}$ value of 0.591 , meaning that the increase in teacher job satisfaction due to the influence of organizational culture is $59.1 \%$. That is, there is a significant influence between organizational culture on teacher job satisfaction.

Table 3 The Significance of the Influence of Organizational Culture on Teacher Job Satisfaction

\begin{tabular}{|c|c|c|c|c|c|c|}
\hline \multicolumn{7}{|c|}{ Coefficientsa } \\
\hline & \multirow{2}{*}{ Model } & \multicolumn{2}{|c|}{$\begin{array}{l}\text { Unstandardized } \\
\text { Coefficients }\end{array}$} & \multirow{2}{*}{$\begin{array}{c}\text { Standardized } \\
\text { Coefficients } \\
\text { Beta } \\
\end{array}$} & \multirow{2}{*}{$\mathrm{t}$} & \multirow{2}{*}{ Sig. } \\
\hline & & B & $\begin{array}{l}\text { Std. } \\
\text { Error }\end{array}$ & & & \\
\hline \multirow[t]{2}{*}{1} & (Constant) & 15,858 & 7,287 & & 2,176 & 0.033 \\
\hline & $\begin{array}{c}\text { Organizational } \\
\text { culture }\end{array}$ & 0.724 & 0.070 & 0.769 & 10,274 & 0.000 \\
\hline
\end{tabular}

a. Dependent Variable: Job satisfaction

Table 4 Summary Model of organizational culture

\begin{tabular}{|l|l|l|l|l|}
\hline Model & $\mathrm{R}$ & R Square & $\begin{array}{c}\text { Adjusted } \\
\text { R Square }\end{array}$ & $\begin{array}{c}\text { Std. Error } \\
\text { of the } \\
\text { Estimate }\end{array}$ \\
\hline 1 & $.769 \mathrm{a}$ & 0.591 & 0.586 & 4.95553 \\
\hline
\end{tabular}

a. Predictors: (Constant), Organizational Culture

b. Dependent Variable: Job satisfaction

\subsection{The Effect of Organizational Commitment and Organizational Culture on Teacher Job Satisfaction}

Simultaneous data analysis used the $\mathrm{F}$ test to determine the effect of organizational commitment variables and organizational culture on teacher job satisfaction. The results of data analysis in Table 5 indicate that the calculated $\mathrm{F}$ value of 56.496 is greater than the $f$ table value of 3.13 , while the significance value of 0.000 is less than 0.05 . This shows that there is a significant influence between organizational commitment and organizational culture together on teacher job satisfaction. The $R$ value of 0.782 can be interpreted that the effect of the two variables in this study is in the strong category (Table 6). The $\mathrm{R}_{\text {Square }}$ score is 0.611 , so it can be interpreted that the influence of organizational commitment and organizational culture contributes up to $61.1 \%$ to teacher job satisfaction.

Table 5 Regression Analysis of Organizational Commitment and Organizational Culture on Job Satisfaction

\begin{tabular}{|c|l|c|c|c|c|c|}
\hline \multicolumn{2}{|c|}{ Model } & $\begin{array}{c}\text { Sum of } \\
\text { Squares }\end{array}$ & df & $\begin{array}{c}\text { Mean } \\
\text { Square }\end{array}$ & F & Sig. \\
\hline \multirow{2}{*}{1} & Regression & 2678,172 & 2 & 1339,086 & 56,496 & $.000 \mathrm{~b}$ \\
\cline { 2 - 8 } & Residual & 1706,574 & 72 & 23,702 & & \\
\cline { 2 - 8 } & Total & 4384,747 & 74 & & & \\
\hline
\end{tabular}

a. Dependent Variable: Job satisfaction

b. Predictors: (Constant), Organizational Culture, organizational commitment

Table 6 Coefficient of Determination

\begin{tabular}{|l|c|l|l|l|l|} 
Model & $\mathrm{R}$ & $\begin{array}{c}\mathrm{R} \\
\text { Square }\end{array}$ & $\begin{array}{c}\text { Adjusted } \\
\text { R Square }\end{array}$ & $\begin{array}{c}\text { Std. Error } \\
\text { of the } \\
\text { Estimate }\end{array}$ & $\begin{array}{l}\text { Durbin- } \\
\text { Watson }\end{array}$ \\
\hline 1 & $.782 \mathrm{a}$ & 0.611 & 0.600 & 4,86851 & 1,731 \\
\hline
\end{tabular}

a. Predictors: (Constant), Organizational Culture, organizational commitment

b. Dependent Variable: Job satisfaction 
This study concludes that there is an effect of organizational commitment on teacher job satisfaction. The effect of organizational commitment on teacher job satisfaction is also shown by several studies conducted by several previous researchers. Research conducted byEslami and Gharakhani [23], Damayanti \& Ismiyati [24], Sestriani \& Kurniawati [25], Azeem [26], and Aydogdu \& Asikgil [27] who concluded that organizational commitment affects job satisfaction, which if there is high organizational commitment, it is certain will create high job satisfaction as well.

Organizational commitment has three indicators, namely teacher willingness, teacher loyalty, and teacher pride. With a strong organizational commitment to the school, it will have an impact on the emergence of an attitude of loyalty, a sense of belonging, and the job satisfaction of teachers with their schools. Therefore, it is very important to increase organizational commitment in the world of education, namely schools, which will increase teacher job satisfaction and the school's vision and mission will be achieved optimally.

This research concludes there isthe influence of organizational culture on teacher job satisfaction. This study is supported by relevant research conducted by several previous researchers, namely research conducted by Bellou [28] which concluded that organizational culture has a significant and positive effect on employee job satisfaction. In school organizations, if the principal as a boss and fellow teacher as colleagues are willing to support each other in all fields of work in accordance with their respective job distribution, then a positive impact will arise naturally, namely the increase in teacher job satisfaction.

This research concludes there is influence organizational commitment and organizational culture to teacher job satisfaction. The results of this study are in line with the results of research conducted by Damayanti \& Ismiyati [24] which showed that Organizational culture and organizational commitment have a positive and significant effect on teacher job satisfaction. Factors that influence job satisfaction according to Mangkunegara [24] are job factors and all that is in the teacher himself. First; The factors contained in the teacher include gender, physical condition, age, education, intelligence, special skills, work experience, years of service, work attitudes, ways of thinking and future views, personality, and emotions. Second; job factors which consist of the type of job, position, quality of supervision, organizational management, rank (class), promotion, social interaction, finance, and work relations.

Other than that, Brown \& Ghiselli [28] stated that there are four factors that are involved raisesjob satisfaction. First, position, usually someone who works in a higher position will feel more satisfied than those who work in a lower position. Second, rank, is to be proud of itself in changing their behavior and feelings. Third, financial and social security. Finance and social security have the biggest influence on job satisfaction. Fourth, quality control. Employee satisfaction can be optimized with good attention and relationships from leaders to subordinates. Thus the teacher will feel that he is an important part of the work organization.

Factors that promote job satisfaction are mentally challenging jobs, appropriate wages, good work situations, partner which supports, the suitability of work with the personality of each individual [28]. Job satisfaction for teachers appears when teachers get good opportunities in the aspects of the dimensions of work, promotion, supervision, peers, work environment and a sense of security. The expectations and goals of the organization are the high commitment of employees to work hard and survive in all conditions so that organizational goals can be realized [28], [29]. An employee will recognize the elements in the organization and their goals by starting with organizational commitment. A person's emotional attachment to the organization which is formed from moral support, organizational judgment and a determination to serve is the cause of organizational commitment. The attitude that shows the closeness and involvement of a person in the organization is called organizational commitment [28], [29].

Organizational commitment is characterized by the emergence of belief and recognition of goals and norms, the desire to achieve goals and survive as a member of the organization, all of which become a psychological bond in a teacher [28], [29]. Organizational commitment is a reflection of teacher loyalty and a continuous process between the attention of organizational members and the belief to get the values and goals of the organization [30].

Organizational commitment is a condition that shows that teachers are in favor of organizational goals and have the willingness to maintain their membership in the organization [28], [29]. Organizational commitment is the level of belief and belief of each person in adhering to the norms, values, goals, and ethical standards of the organization as well as the attitude of loyalty to the organization it follows [31]. Organizational commitment can be interpreted as a teacher's sense of unity with their organization [31].

Based on the explanations above, it can be concluded that organizational commitment is the attitude of the teacher which is closely related to belief and recognition of organizational goals and norms, as well as a strong will to survive as an active and efficient member of the organization. Organizational goals will be achieved optimally if employees or teachers are loyal and willing to work hard to achieve maximum organizational results. Organizational commitment is created gradually in each individual teacher. Initially only personal needs or interests in the organization, over time a sense of togetherness arose and increased to a sense of belonging to the organization that was followed. 
Teacher organizational commitment has a significant relationship with what a teacher experiences as a member of the organization [28]. The sense of pride and belonging to the school organization is reflected in the attitudes and actions of the teachers, including loyalty, both to fellow teachers and to the principal as superiors. In addition, the good intentions of teachers to maintain the good name of the school under any circumstances are also a process of organizational commitment [32], [33]. The commitment of the teacher, which becomes a collective agreement, consists of the goals to be achieved, the rules that must be obeyed, the activities that must be carried out, the necessary means, and determining the best way or method to achieve these goals.

After understanding the meaning of culture, what is associated with it is the organization. An organization is an arrangement of fellowship between two or more people who make an agreement to work hard together to achieve goals [32], [33]. Each member of the organization has their respective duties and roles according to the patterns and boundaries that are used to separate the members of the organization and their environment. Therefore, the organization is declared as a social unit consisting of interacting human beings.

Culture can define identity and the continuation of an organization's life direction; Organization helps someone to fix his shortcomings in achieving common goals. So, organizational culture can reach deeper and broader aspects for the realization of an ideal organizational climate [32], [33]. School culture is often referred to as a work climate which describes the atmosphere of working relationships between teachers, between teachers and school principals, between teachers and other education personnel, and between agencies in their environment as a form of a conducive environment [32], [33].

An organization consisting of at least two people who have the same passion and desire to achieve the same goals. Organizations make work patterns that are arranged in such a way. It cannot be denied that the organization becomes a social unit that is deliberately formed over a long period of time [32], [33]. By utilizing existing resources in the form of funds, facilities and infrastructure, and supporting data, an organization will achieve its goals. Setting up an organization as a forum for fellowship is not easy. All of this must be encouraged by cooperation that is rational and systematic, planned, guided and controlled.

Organizations are made by humans and their members are also a group of people who have regular work patterns to achieve common goals [28]. Organizations have special characteristics in the social aspect, have at least two members, have an orderly work system, have goals, and have different identities [34], [35]. Organizations are formed by people who have high insight, skills, and supporting infrastructure
[36], [37]. A collection of two or more people who have good regularity and coordination [38]. If it is not coordinated, then a collection of two or more people is not an organization. The organization becomes a forum to ease the burden on each other between members in order to achieve common goals that have been agreed upon [39], [40]. The differences in character and identity of members make the atmosphere more colorful in the organization.

\section{CONCLUSION}

Based on the results of data analysis, it is concluded that organizational culture and organizational commitment have a simultaneous effect on job satisfaction guru, with a contribution of $61.1 \%$ while the remaining $38.9 \%$ is explained by other factors not examined in this study. A strong organizational culture will trigger teachers to think, behave, and behave in accordance with organizational values. The match between organizational commitment and organizational culture with organizational members who support it will lead to job satisfaction, thus encouraging teachers to improve performance for the better. If teacher performance increases, teacher job satisfaction will also be achieved.

\section{ACKNOWLEDGMENTS}

Thanks are given to teachers who have helped in the process of collecting research data. Thank to the Rector of Universitas PGRI Palembang, the Director of the Postgraduate Program, and the Chair of the Educational Management, for who has provided guidance. Then thank you also to the friends of the Universitas PGRI Palembang and all those who have helped write and publish this article.

\section{REFERENCES}

[1] A. Sobirin, "Budaya Organisasi Pengertian, Makna dan Aplikasinya dalam Kehidupan Organisasi”. Yogyakarta: IBPP STIM YKPN, 2007.

[2] Arafat. "Pengaruh Komitmen Organisasi dan Motivasi Kerja Terhadap Kinerja Guru". JMKSP, Vol. 6, No. 1 Januari-Juni 2021. Palembang: Universitas PGRI, 2020.

[3] K. I. Arishanti, "Pengaruh Budaya Organisasi dan Komitmen Organisasional terhadap Kepuasan Kerja Karyawan. Proceeding PESAT: Psikologi, Ekonomi, Sastra, Arsitektur, \& Sipil, Vol 3, 2009

[4] N. Chatab, "Profil Budaya Organisasi". Bandung: Alfabeta, 2012.

[5] C. M. Taurisa, and I. Ratnawati, "Analisis Pengaruh Budaya Organisasi dan Kepuasan Kerja terhadap Komitmen Organisasional dalam Meningkatkan Kinerja Guru (Studi pada PT. Sido Muncul Kaligawe Semarang). Jurnal Bisnis dan Ekonomi (JBE), Vol. 19, No. 2, p. 170-187, 2012. 
[6] E. Damayanti, and I. Ismiyati, "Pengaruh Kompensasi, Lingkungan Kerja, dan Budaya Organisasi terhadap Kepuasan Kerja Guru". Economic Education Analysis Journal, Vol. 9, No. 1, p. 33-49, 2020.

[7] D. Darmawan, "Peranan Motivasi Kerja, Komitmen Organisasi dan Budaya Organisasi terhadap Kepuasan Kerja”. Jurnal Ilmiah Manajemen Pendidikan Indonesia, Vol. 2, No. 3, 2016.

[8] P. Eddy, "Pengaruh Budaya Sekolah dan Diklat terhadap Kinerja Guru". Journal of Education Research. Palembang: UPGRI, 2020.

[9] H. A. Fattah, "Kepuasan Kerja dan Kinerja Pegawai". Yogyakarta: Elmatera, 2019.

[10] W. Hasbi, A. W. Handaru, and A. Pangeran, "Pengaruh Budaya Organisasi dan Komitmen Organisasi terhadap Kepuasan Kerja Karyawan pada PT. Nutrifood Indonesia di Jakarta”, Jurnal Riset Manajemen Sains Indonesia (JRMSI), Vol. 4, No. 1, 2013.

[11] M. S. P. Hasibuan, "Manajemen Sumber Daya Manusia". Jakarta: PT. Bumi Aksara, 2012.

[12] N. Kesumawati, adn Aridanu, I., "Statistik Parametrik Penelitian Pendidikan". Depok: Raja Grafindo Persada, 2017.

[13] R. Kreitner, adn A. Kinicki, "Perilaku Organisasi”. Jakarta: Salemba Empat, 2011.

[14] F. Luthans, "Perilaku Organisasi". Yogyakarta: Penerbit Andi, 2009.

[15] A. A. Mangkunegara, "Manajemen Sumber Daya Manusia". Bandung: PT. Remaja Rosdakarya, 2009.

[16] A. Mangkunegara, "Manajemen Sumber Daya Manusia Perusahaan". Bandung: Remaja Rosdakarya, 2013.

[17] G. Moorhead, and R. W. Griffin, "Perilaku Organisasi”. Jakarta: Salemba Empat, 2013.

[18] I. Gunawan, "Pengantar Statistika Inferensial". Jakarta: Rajawali Pers, 2016.

[19] I. Gunawan, "Introduction to inferential statistics". Jakarta: PT Raja Grafindo Persada, 2016.

[20] I. Gunawan, "Statistika untuk Kependidikan Sekolah Dasar". Yogyakarta: Penerbit Ombak Yogyakarta, 2013.

[21] S. Hadi, I. Gunawan, and J. Dalle, "Statistika Inferensial: Teori dan Aplikasinya". Jakarta: Rajawali Pers, 2018.

[22] Sugiyono, "Metode Penelitian Kuantitatif, Kualitatif dan R\&D”. Bandung: Alfabeta, 2012.

[23] Z. A. Noor, "Pengaruh Budaya Organisasi, Komitmen Organisasi, dan Motivasi Kerja terhadap Kepuasan Kerja dan Kinerja Karyawan". Ekuitas: Jurnal Ekonomi dan Keuangan, Vol. 16, No. 4, p. 473- 486, 2012.

[24] M. Z. Roziqin, "Kepuasan Kerja". Malang: Averroes Press, 2010.
[25] S. Sagala, "Kemampuan Profesional Guru dan Tenaga Kependidikan". Bandung: Alfabeta, 2009.

[26] S. P. Siagian, "Sistem Informasi Manajemen". Jakarta: PT. Bumi Aksara, 2013.

[27] Sopiah, "Perilaku Organisasi". Yogyakarta: Andi Offset, 2008.

[28] S. P. Robbins, "Perilaku Organisasi". Jakarta: Salemba, 2008

[29] S. P. Robbins, "Perilaku Organisasi". Jakarta: Salemba, 2012.

[30] Y. Supiyanto, "Pengaruh Kompensasi, Kompetensi dan Komitmen Organisasional terhadap Kepuasan Kerja dan Kinerja Karyawan Koperasi. Universitas PGRI Ronggolawe, 2015.

[31] E. Sutrisno, "Manajemen Sumber Daya Manusia”. Jakarta: Kencana, 2011.

[32] H. A. R Tilaar, "Pendidikan Kebudayaan dan Masyarakat Madani Indonesia". Bandung: Remaja Rosda Karya, 2004.

[33] Undang-undang Nomor 20 Tahun 2003 tentang Sistem Pendidikan Nasional.

[34] Wibowo, "Manajemen Perubahan". Jakarta: PT. Raja Grafindo Persada, 2006.

[35] T. A. Wijaya, "Tanya Jawab Budaya Organisasi”. Jakarta: Penerbit Harvarindo, 2004.

[36] N. W. N. Setya, I. Gunawan, D. E. Kusumaningrum, R. B. Sumarsono, A. Nurabadi, L. K. Hui, ... \& F. B. Santoso, "Development of Student Leadership Variables Instruments: Validity and Reliability Analysis". In 1st International Conference on Information Technology and Education (ICITE 2020) (pp. 541-545), Atlantis Press, 2020.

[37] A. Prastiawan, I. Gunawan, A. P. Putra, D. A. Dewantoro, P. S. Cholifah, N. L. S. Nuraini, ... \& E. Surahman, "School Leadership Skills in Educational Institutions". In 6th International Conference on Education and Technology (ICET 2020) (pp. 438-441), Atlantis Press, 2020.

[38] A. Nurabadi, I. Bafadal, E. T. Priyatni, \& I. Gunawan, "Analysis of the Availability of School Facilities and Infrastructure as an Effort to Accelerate School Quality Improvement". In 6th International Conference on Education and Technology (ICET 2020) (pp. 89-92), Atlantis Press, 2020.

[39] I. Gunawan, I. Bafadal, \& A. Nurabadi, "School Leadership Strategy in Excellent Schools". In 6th International Conference on Education and Technology (ICET 2020) (pp. 210-215), Atlantis Press, 2020.

[40] A. N. Faizah, I. Gunawan, I. Bafadal, \& A. Timan, "The Relationship between Learning Leadership and Teacher Performance: A Correlation Analysis". In 1st International Conference on Information Technology and Education (ICITE 2020) (pp. 599-602), Atlantis Press, 2020. 